\title{
Risk Management in Construction Projects
}

\author{
Nerija Banaitiene and Audrius Banaitis
}

Additional information is available at the end of the chapter

http://dx.doi.org/10.5772/51460

\section{Introduction}

The financial and economic crisis has had an adverse impact on the Lithuania's economy and construction industry. The GDP of Lithuania grew slightly in 2010, in contrast to a decrease of $14.7 \%$ in 2009. Lithuania's GDP increased from $1.3 \%$ in 2010 to $4.6 \%$ in 2011. Annual GDP growth decreased from its highest point of $6.7 \%$, reached in the third quarter, to $4.4 \%$ in the last quarter of 2011 [1,2]. Some industries, such as construction; trade, transport and communications; and the industry sectors were most affected by the crisis. In 2010 , the gross value added within the construction sector decreased by $43.3 \%$, and in the trade, transport and communications sector - by $16.6 \%$. In 2011, a positive change in the gross value added was observed in all groups of economic activities. The largest growth in the gross value added was observed in enterprises engaging in construction (by 15\%) and trade, transport and communication services (7.3\%) [1,3]. The construction sector, one of the engines of economic growth in Lithuania over the last decade, is now facing with serious challenges as companies' closures, rising unemployment, and postponed or even cancelled investments. These events also have changed the clients' and construction companies' behaviour. A reduced demand and shortage of orders dramatically increased a competition between companies of the construction sector. This increased pressure to improve quality, productivity and reduce costs, and the need for project strategies and management that can appropriately and effectively manage project risk.

Risk management is one of the nine knowledge areas propagated by the Project Management Institute [4]. Furthermore, risk management in the construction project management context is a comprehensive and systematic way of identifying, analyzing and responding to risks to achieve the project objectives $[5,6]$. The benefits of the risk management process include identifying and analyzing risks, and improvement of construction project management processes and effective use of resources.

Construction projects can be extremely complex and fraught with uncertainty. Risk and uncertainty can potentially have damaging consequences for the construction projects $[7,8]$. 
Therefore nowadays, the risk analysis and management continue to be a major feature of the project management of construction projects in an attempt to deal effectively with uncertainty and unexpected events and to achieve project success.

Construction projects are always unique and risks raise from a number of the different sources $[9,10]$. Construction projects are inherently complex and dynamic, and involving multiple feedback processes [11,12]. A lot of participants - individuals and organisations are actively involved in the construction project, and they interests may be positively or negatively affected as a result of the project execution or project completion [4]. Different participants with different experience and skills usually have different expectations and interests [13]. This naturally creates problems and confusion for even the most experienced project managers and contractors.

Cost of risk is a concept many construction companies have never thought about despite the fact that it is one of the largest expense items [14]. Risk management helps the key project participants - client, contractor or developer, consultant, and supplier - to meet their commitments and minimize negative impacts on construction project performance in relation to cost, time and quality objectives. Traditionally, practitioners have tended to associate construction project success with these three aspects of time, cost and quality outcomes.

The current economic downturn and challenges in a highly competitive Lithuania's construction sector require contractors to manage risks by themselves. This paper reports the research that aims to examine the risk analysis and risk management practices in the Lithuanian construction companies.

\section{Literature review}

In today's post-crisis economy effective risk management is a critical component of any winning management strategy. Risk management is one of the nine knowledge areas propagated by the Project Management Institute (PMI). The PMBOK® Guide recognises nine knowledge areas typical of almost all projects. The nine knowledge areas are [4]:

1. Project integration management.

2. Project scope management.

3. Project time management.

4. Project cost management.

5. Project quality management.

6. Project human resource management.

7. Project communications management.

8. Project risk management.

9. Project procurement management.

Although these knowledge areas are all equally important from a project manager's point of view, in practice a project manager might determine the key areas which will have the greatest impact on the outcome of the project. 
Each PMI knowledge area in itself contains some or all of the project management processes. For example, project risk management includes [4]:

- Risk management planning;

- Risk identification;

- Qualitative risk analysis;

- Quantitative risk analysis;

- Risk response planning;

- $\quad$ Risk monitoring and control.

Risk management is probably the most difficult aspect of project management. A project manager must be able to recognise and identify the root causes of risks and to trace these causes through the project to their consequences. Furthermore, risk management in the construction project management context is a comprehensive and systematic way of identifying, analyzing and responding to risks to achieve the project objectives $[5,6]$. The use of risk management from the early stages of a project, where major decisions such as choice of alignment and selection of construction methods can be influenced, is essential [15]. The benefits of the risk management process include identifying and analyzing risks, and improvement of construction project management processes and effective use of resources.

The construction industry is heterogeneous and enormously complex. There are several major classifications of construction that differ markedly from one another: housing, nonresidential building, heavy, highway, utility, and industrial [16]. Construction projects include new construction, renovation, and demolition for both residential and nonresidential projects, as well as public works projects, such as streets, roads, highways, utility plants, bridges, tunnels, and overpasses. The success parameters for any project are in time completion, within specific budget and requisite performance (technical requirement). The main barriers for their achievement are the change in the project environment. The problem multiplies with the size of the project as uncertainties in project outcome increase with size $[17,18]$. Large construction projects are exposed to uncertain environment because of such factors as planning, design and construction complexity, presence of various interest groups (owner, consultants, contractors, suppliers, etc.), resources (manpower, materials, equipment, and funds) availability, environmental factors, the economic and political environment and statutory regulations.

Construction projects can be unpredictable. Managing risks in construction projects has been recognized as a very important process in order to achieve project objectives in terms of time, cost, quality, safety and environmental sustainability [19]. Project risk management is an iterative process: the process is beneficial when is implemented in a systematic manner throughout the lifecycle of a construction project, from the planning stage to completion.

In the European Union construction is the sector most at risk of accidents, with more than 1300 people being killed in construction accidents every year. Worldwide, construction workers are three times more likely to be killed and twice as likely to be injured as workers in other occupations. The costs of these accidents are immense to the individual, to the employer and to society. They can amount to an appreciable proportion of the contract price [20]. 
Construction activities in Lithuania provided employment to an estimated 93.7 thousand persons in 2011, while an annual turnover in excess of EUR 1.91 billion [21]. Construction is one of Lithuania's largest industries. Unfortunately it has also the occupational health and safety problems. More construction workers are killed, injured or suffer ill-health than in any other industry. In 2011, 13 construction workers killed whilst at work, compared to 7 industrial workers and 4 agricultural workers. In comparison with 2010, the number of fatal accidents in construction enterprises increased by more than 2 times, i.e. from 6 to 13 cases has been reported [22].

The risk analysis and management techniques have been described in detail by many authors [23-27]. A typical risk management process includes the following key steps [28]:

- $\quad$ Risk identification;

- $\quad$ Risk assessment;

- Risk mitigation;

- $\quad$ Risk monitoring.

Risk identification is the first and perhaps the most important step in the risk management process, as it attempts to identify the source and type of risks. It includes the recognition of potential risk event conditions in the construction project and the clarification of risk responsibilities [29]. Risk identification develops the basis for the next steps: analysis and control of risk management. Corrects risk identification ensures risk management effectiveness. Carbone and Tippett [30] stated that the identification and mitigation of project risks are crucial steps in managing successful projects.

The PMBOK® Guide [4] defines a project risk as "an uncertain event or condition that, if it occurs, has a positive or negative effect on at least one project objective". There are many possible risks which could lead to the failure of the construction project, and through the project, it is very important what risk factors are acting simultaneously. As stated by Raz et al. [31], too many project risks as undesirable events may cause construction project delays, excessive spending, unsatisfactory project results or even total failure.

Many approaches on risk classification have been suggested in the literature for effective construction project risk management. Tah and Carr [32] categorized risks into two groups in accordance with the nature of the risks, i.e. external and internal risks. Combining the fuzzy logic and a work breakdown structure, the authors grouped risks into six subsets: local, global, economic, physical, political and technological change. According to Wang et al. [33], the classification of the risks depends mainly upon whether the project is local or international. The internal risks are relevant to all projects irrespective of whether they are local or international. International projects tend to be subjected to the external risk such as unawareness of the social conditions, economic and political scenarios, unknown and new procedural formalities, regulatory framework and governing authority, etc.

According the PMBOK® Guide [4], the risks are categorized into such groups: technical, external, organizational, environmental, or project management. Some categories of risk that affect a construction project are similar to risks for other investment projects, whether it is an 
investment in common stocks or government bonds, and some are specific to construction. The risk identification process would have highlighted risks that may be considered by project management to be more significant and selected for further analysis [34]. Risk identification is an iterative process because new risks may become known as the project progresses through its life cycle and previously-identified risks may drop out [35]. Construction projects carry complex risks for all involved-including owners, consultants, contractors, and suppliers - that can increase when construction takes place near an active facility or congested area. Risks include geological or pollution-related conditions, interference with ongoing operations, construction accidents, as well as design and construction faults that may negatively impact the project both construction and when the project is complete.

Generally two broad categories, namely, qualitative and quantitative analysis are distinguished in literature on risk assessment. A qualitative analysis allows the key risk factors to be identified. Risk factors may be identified through a data-driven (quantitative) methodology or qualitative process such as interviews, brainstorming, and checklists. It is considered as an evaluation process which involves description of each risk and its impacts or the subjective labelling of risk (high/medium/low) in terms of both risk impact and probability of its occurrence [19]. Qualitative risk analysis assesses the impact and likelihood of the identified risks and develops prioritized lists of the risks for further analysis or direct mitigation. Carr and Tah [36] introduced a hierarchical risk breakdown structure (HRBS), and the HRBS represents a formal model for qualitative risk assessment. Quantitative analysis involves more sophisticated techniques and methods to investigate and analyze construction project risks. Quantitative risk analysis attempts to estimate the frequency of risks and the magnitude of their consequences by different methods such as the decision tree analysis, the cost risk analysis, and Monte Carlo simulation [37]. The application of the quantitative risk analysis allows the construction project exposure to be modelled, and quantifies the probability of occurrence of the identified risk factors as well as their potential impact.

Various risk management tools are available, but unfortunately they are not suitable for many industries, organizations and projects [38]. Although today's organizations appreciate the benefits of managing risks in construction projects, formal risk analysis and management techniques are rarely used due to lack of knowledge and to doubts on the suitability of these techniques for construction projects.

There are four alternative strategies - risk avoidance, risk transfer, risk mitigation, and risk acceptance, for treating risks in a construction project. As stated by Hillson [39], risk mitigation and risk response development is often the weakest part of the risk management process. The proper management of risks requires that they be identified and allocated in a well-defined manner. This can only be achieved if contracting parties comprehend their risk responsibilities, risk event conditions, and risk handling capabilities [40].

Before the crisis (2004-2008), due to a lack of contractors' responsibilities and control in various steps of a project's development, the time and quality performance levels of 
construction projects in the Lithuania were generally inadequate or even poor. In construction projects, many parties are involved such as owner, consultant, contractor, subcontractor, and supplier. Each party has its own risks. Risk transfer means the shift of risk responsibility to another party either by insurance or by contract. Wang and Chou [29] reported that contractors usually use three methods to transfer risk in construction projects:

- $\quad$ through insurance to insurance companies;

- through subcontracting to subcontractor;

- $\quad$ through modifying the contract terms and conditions to client or other parties.

Construction projects can be managed using various risk management tools and techniques. Ahmed et al. [23] reviewed techniques that can be used for development of risk management tools for engineering projects. Techniques for context establishment, risk identification, risk assessment and treatment were provided. Application of risk management tools depends on the nature of the project, organization's policy, project management strategy, risk attitude of the project team members, and availability of the resources [12]. A risk assessor model (RAM) presented by Jannadi and Almishari [41] was developed to determine risk scores for various construction activities. The model provides an acceptability level for the risks and determines a quantitative justification for the proposed remedy.

Risks and uncertainties, involved in construction projects, cause cost overrun, schedule delay and lack of quality during the progression of the projects and at their end [28,29,42]. As stated by Baloi and Price [43], poor cost performance of construction projects seems to be the norm rather than the exception, and both clients and contractors suffer significant financial losses due to cost overruns.

Oyegoke et al. [44] discusses the problems of managing risk and uncertainty in construction project due to the owner dissatisfaction in project outcome and dynamism within agile construction environment. The authors identified some areas in supply chain processes which are prone to greater risks and uncertainty and propose an agile management principle based on the concept of integration and fragmentation in product development and execution processes respectively.

Many authors have reviewed problems on time performance in construction projects $[43,45,46]$. Aibinu and Odenyinka [46] investigated and assessed the causes of delays in building projects in Nigeria. The nine factor categories evaluated include: client-, contractor-, quantity surveyor-, architect-, structural engineer-, services engineer-, supplier-, and subcontractor-caused delays, and external factors (i.e. delays not caused by the project participants). Finally, ten overall delay factors were identified, namely: contractors' financial difficulties, client' cash flow problems, architects' incomplete drawings, subcontractors' slow mobilization, equipment break-down and maintenance problems, suppliers; late delivery of ordered materials, incomplete structural drawings, contractors' planning and scheduling problems, price escalation, and subcontractors' financial difficulties. The authors pointed the poor risk management as one of the principal delay factors and concluded that actions and inactions of construction project participants contribute to overall project delays. 
According to Baloi and Price [43], the construction contractors highlight that delay in payments is common both in private and public projects, with the public sector being the worse defaulter. Moreover, most types of contracts presume compensation clauses for delay in payments, but clients rarely agree to pay the interests due to the contract. Nasir et al. [47] analysed schedule risks and developed a comprehensive construction schedule risk model is referred to as Evaluating Risk in Construction-Schedule Model (ERIC-S). The ERIC-S model provides decision support to project owners, consultants, and researchers as a project delay prediction tool. Similarly, the Cost-Time-Risk diagram (CTR) proposed by Aramvareekul and Seider [48] helps project managers consider project risk issues while monitoring and controlling their project schedule and cost performance in one diagram.

The performance by the project management team highly influences the success of a construction project. Some of the incidental risks associated with poor project management performance are [49]:

- Unclear or unattainable project objectives;

- Poor scoping;

- Poor estimation;

- $\quad$ Budget based on incomplete data;

- Contractual problems;

- Insurance problems;

- Delays;

- Quality concerns;

- Insufficient time for testing.

Many authors have recognized the value of trust within the project business. Lewicki and Bunker [50] emphasize that trust is a critical success element to most business, professional, and employment relationships. Trust is argued to improve the inter-organizational relationships among principal actors in project development, such as owners, contractors, and suppliers [51]. According by Krane et al. [52] trust between project owners and project managers is crucial for project success.

In business relations, as stated by Kaklauskas et al. [53], the global economic crisis brought about distrust of other stakeholders. Trust reinforces the relationships of the critical stakeholder that often determine the success of a project [51,54,55]. Ward and Chapman [56] concluded that stakeholders are a major source of uncertainty in construction projects. Smyth et al. [57] note that trust provides an important resource for creating greater probability and certainty. Wilkinson [58] found that project management companies need to overcome problems in their relationships with other professionals on the project team and with the client. For the success of construction projects, there is a need for alignment of the project owners' interests and the project management team's interests and trust between them.

Construction projects are tendered and executed under different contract systems and payment methods [59]. According by Zaghloul and Hartman [60], there is no possibility to 
eliminate all the risks associated with a specific project. All that can be done is to regulate the risk allocated to different parties and then to properly manage the risk. Chapman and Ward [61] argue that the contract choice decisions are central to both stakeholder management and the management of risk and uncertainty. The authors proposed an integrated approach based on a balanced incentive and risk sharing (BIARS) approach to contracting as well as a best practice approach to risk management in terms of the whole project life cycle.

Contractors generally aim to make an acceptable range of profit margin. Profit margins in the industry have been low for most contractors on projects in recent years. Correct understanding and allocation of risk helps for contractors to avoid erosion of the profit margin. Ökmen and Öztas [62] proposed a new simulation-based model - the correlated cost risk analysis model (CCRAM) - to analyse the construction costs under uncertainty when the costs and risk-factors are correlated. The CCRAM model captures the correlation between the costs and risk-factors indirectly and qualitatively. Baloi and Price [63] determined the most critical risk factors affecting construction cost performance. The authors stated that global risk factors pose more challenges to contractors, which are less familiar with them. The authors introduced a fuzzy decision framework for a systematic modelling, analysis and management of global risk factors affecting construction cost performance from contractor's perspective and at a project level. Similarly, Ismail et al. [64] provide a 'Level-Severity-Probability' approach to determine the critical risk source and factors. Fuzzy logic is used in the proposed methodology for evaluation of the risk level, severity and probability. As stated by Zeng et al. [65], the application of fuzzy reasoning techniques provides an effective tool to handle the uncertainties and subjectivities arising in the construction project.

The review of the literature revealed a wide range of risk types and sources in construction projects, and that various risk management methods and techniques can be employed in the management of construction projects in order to control potential risks.

\section{Methods and data}

The aims of the research were: first, to identify contractors' opinion on the significance of the construction projects risks; and second, to explore the risk analysis and risk management practices in the Lithuanian construction companies.

The initial survey was distributed during February through March 2008. A second, similar questionnaire was distributed during February through March 2009. A questionnaire containing three sections was developed to facilitate data collection. The first section includes the respondents' opinion on the risk factor in terms of its probability and impact to overall construction project success. The second section includes the respondents' opinion on the risk consequences for construction project performance measures as well as the risk assessment and response practices. The third section aims to collect the background information of the respondents, e.g. their age, gender, position, education, work experience and professional background. 
The questionnaire of first survey was distributed either personally or via e-mail to 40 members of top and middle management in the construction companies. A sample of 40 practitioners received the questionnaire and 38 valid questionnaires were returned for analysis with a response rate of $95 \%$. The second questionnaire was distributed either personally or via e-mail to 35 members of top and middle management in the construction companies. Of the 35 questionnaires distributed in the second survey, 35 were returned, but 5 were incompletely completed and so were excluded from the data analysis. The response rate was $86 \%$.

In both surveys, the baseline characteristics of the respondents were relatively similar. Of the 38 respondents in the first study, site managers comprise $29 \%$, project managers $26 \%$, other position senior managers $21 \%$, civil engineers $16 \%$, and designing engineers $8 \%$. Of the 30 respondents in the second study, site managers, project managers, and other position senior managers comprise $80 \%$.

The Likert scale was selected to obtain the probability of the risk factors in construction project that are identified in the literature review. A 5-point Likert scale was adopted, where 1 represented "rare", 2 "occasional", 3 "somewhat frequent", 4 "frequent", and 5 "very frequent". Likewise, the Likert scale was selected to obtain the impact of the risk factors in construction project that are identified in the literature review. A 5-point Likert scale was adopted, where 1 represented "very low", 2 "low", 3 "moderate", 4 "high", and 5 "very high".

The latest survey was carried out in December 2010-January 2011. In a subsequent study, the role of risk factors at a project level was addressed. A questionnaire containing three sections was developed to facilitate data collection. The first section includes the respondents' opinion on the risk consequences for construction project performance measures as well as the risk assessment and response practices. The second section includes the respondents' opinion on the risk factor in terms of its probability and impact to overall construction project success. The third section aims to collect the background information of the respondents, e.g. their age, gender, position, education, work experience and professional background.

The third questionnaire was distributed either personally or via e-mail to 23 members of top and middle management in the construction company and 23 valid questionnaires were returned for analysis in time to be included in the analysis (100\% overall response rate). Of the 23 respondents in the study, site managers, project managers, and other position senior managers comprise $91 \%$.

In all surveys, the majority of the respondents have more than 15 years' experience in construction/project management or working knowledge of construction/project management activities. Based on work experience and employment position, it was inferred that the respondents have adequate knowledge of the activities associated with construction project risk. This makes them as reliable and credible sources of information which is crucial to satisfy the research goal. The procedure, findings, and relevant discussion of the analyses are detailed in the following section. 


\section{Results}

As outlined in Section 2, risk factors on construction projects can be split into two major groups:

1. Internal risks, which fall within the control of clients, consultants and contractors.

2. External risks, which include risk elements that are not in the control of key stakeholders.

The potential risk sub-factors were adapted from studies by Chapman and Ward [25], Tah and Carr [32], Perera et al. [40], Pinto et al. [51], Baloi and Price [63], Kartam and Kartam [66], Lahdenperä [67], Majamaa et al. [68], Mbachu and Nkado [69], Mitkus and Trinkūnienè [70], and Yang et al. [71].

In order to illustrate the respondents' opinions regarding the importance of analysed risk factors, an average was calculated for each factor. Next, the Kendall coefficient of concordance $\mathrm{W}[72,73]$ was calculated to test the reliability of the responses, and significance testing was based on the Chi-square distribution at the $1 \%$ significance level. The $W$ coefficients were calculated for each defined group of risk factors created by the analysis perspectives.

In both surveys, the respondents agree as regards the external risks impact and probability. The respondents agree as regards the external risks impact, what can be judged by values $W=0.183 ; \chi^{2}=34.7(\alpha=0.01)$, in the first survey; $W=0.10 ; \chi^{2}=12.4(\alpha=0.01)$, in the second survey. The identified external risks according to their potential effect on construction project objectives were ranked. In the first survey, the top three important external risks identified are:

1. Natural forces;

2. Inflation and interest rate;

3. Fiscal policy.

In the second survey, the top three important external risks identified are:

1. Fiscal policy;

2. Natural forces;

3. Political controls.

Probability assessment of risks of the external project constrains is reflected in Fig. 1. Impact assessment of risks of the external project constrains is reflected in Fig. 2.

The risk management perceivers are the project participants, and a contractor is any entity which has the power to influence project decision making directly. Related to experience, only $11 \%$ of the respondents affirmed that they have experience in risk management. Most of them are project manager and have more than 15 years' experience; it proofs that the relationship between risk perception and experience of respondents. And even $34 \%$ of the respondents affirmed that they have no experience in risk management, while $55 \%$ of the respondents affirmed that they do not have enough experience in risk management. And 
$97 \%$ of the respondents answered that risks must be managed at the early stages of the construction project.

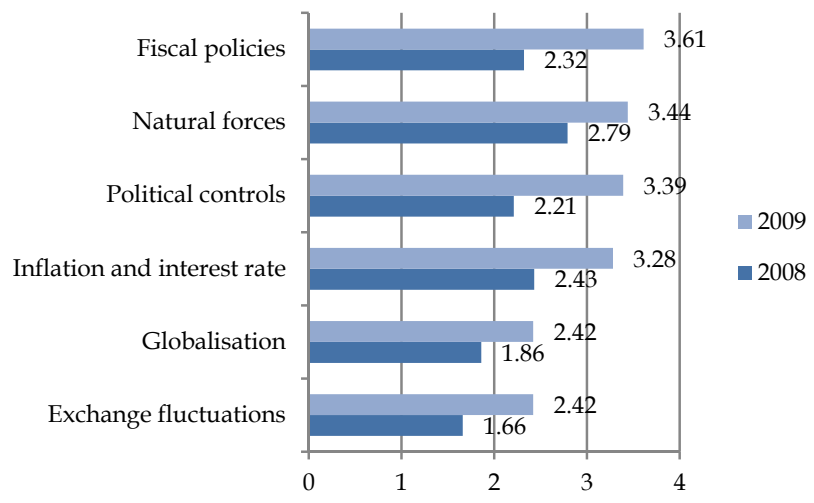

Figure 1. Probability assessment of external project risks

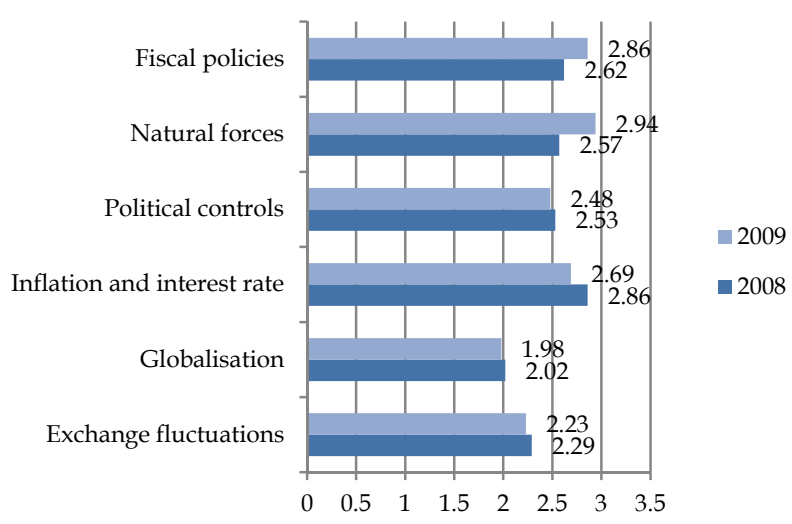

Figure 2. Impact assessment of external project risks

In terms of the sources and providers of the data and information required in the risk analysis, the most frequently used technique is experiential or documented knowledge analysis with $92 \%$ of the respondents' agreement in the first survey, and $93 \%$ of the respondents' agreement in the second survey (Fig. 3). And the project documentation reviews, project team brainstorming, and analysis of other information resources are frequently used in the risk assessment.

Comparison between the two surveys in terms of risk analysis showed a decrease in reviews of project documentation, from $63 \%$ in the first survey to $47 \%$ in the second survey, as well as greater use of experts' judgement, from $26 \%$ in the first survey to $43 \%$ in the second 
survey, and project team brain-storming, from $45 \%$ in the first survey to $53 \%$ in the second survey, in the risk assessment.

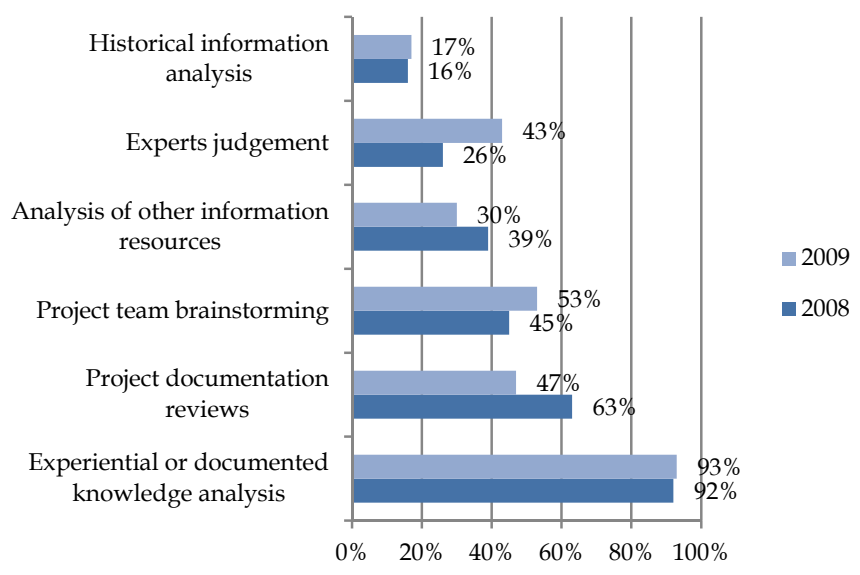

Figure 3. Risk analysis practices in construction projects

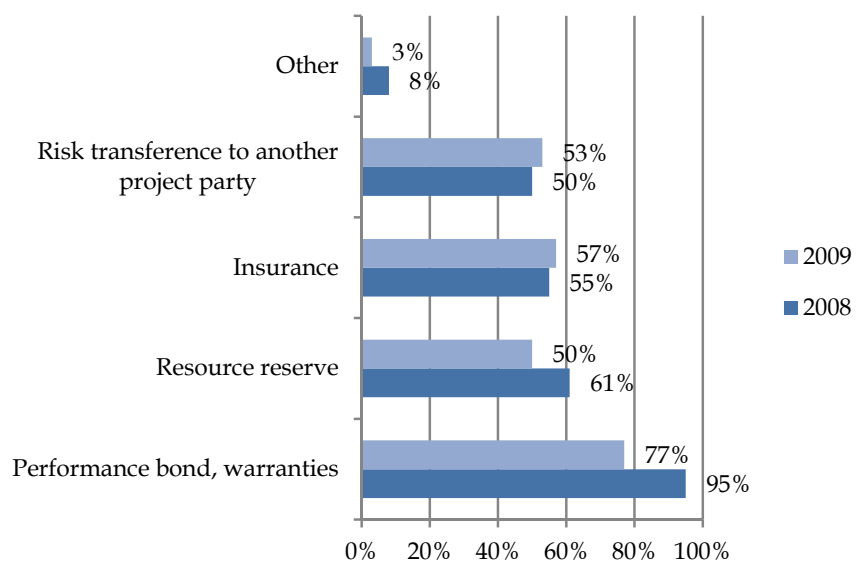

Figure 4. Risk response techniques employed for construction projects

In terms of the risk response tools and techniques, the most frequently used tool is performance bonds and warranties with $95 \%$ of the respondents' agreement in the first survey, and $77 \%$ of the respondents' agreement in the second survey (Fig. 4). And the some resource reservation, insurance, and risk transference to another project party are frequently used risk response techniques.

Comparison between the two surveys in terms of risk response tools and techniques showed a decrease of performance bond and warranties, from $95 \%$ in the first survey to $77 \%$ in the 
second survey, and resource reservation, from $61 \%$ in the first survey to $50 \%$ in the latter survey; as well as greater use of risk transference to another party, from $50 \%$ in the first survey to $53 \%$ in the second survey, and insurance, from $55 \%$ in the first survey to $57 \%$ in the latter survey, for the risk responses.

In last survey (2010-2011), the respondents agree as regards the project level risks impact, what can be judged by values $W=0.54 ; \chi^{2}=51.3(\alpha=0.01)$. As regards the assessment of the project level risks probability, respondents also agree what can be judged by values $W=0.51$; $\chi^{2}=48.5(\alpha=0.01)$. The identified project level risks according to their potential effect on construction project objectives were ranked. The top three important categories of internal risks identified are:

1. Construction risks;

2. Design risks;

3. Project management risks.

Overall assessment of risks of the internal project risks is reflected in Fig. 5. Risk priority is utilized during response planning and risk monitoring. It is critical to understand the priority for each risk as it allows the project team to properly understand the relative importance of each risk.

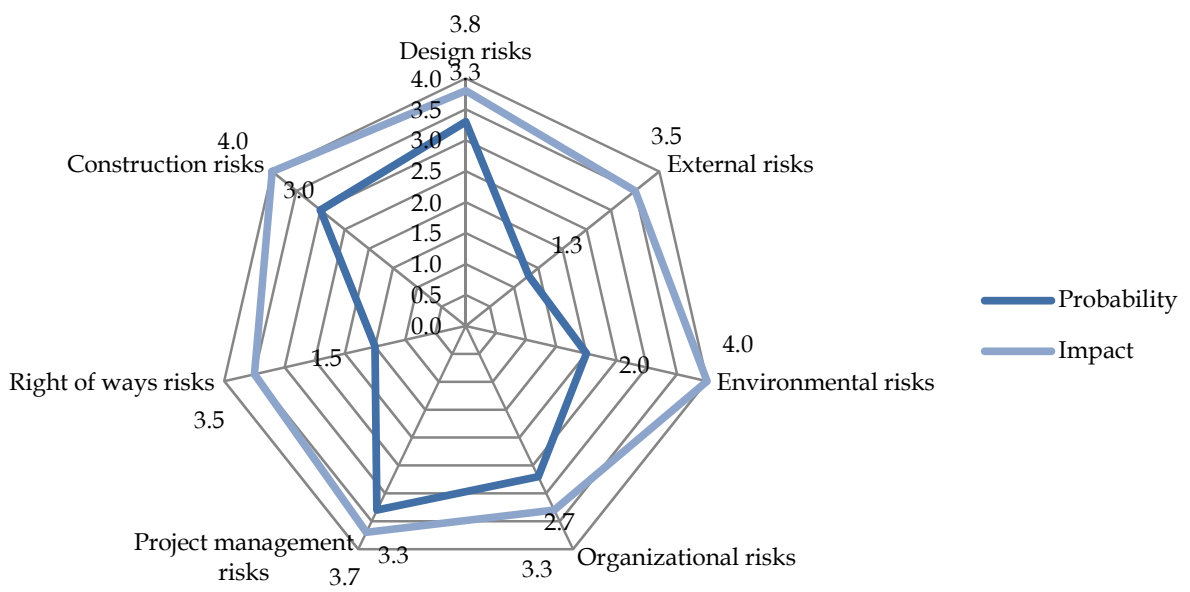

Figure 5. Assessment of project level risk categories

Table 1 shows that the controllable risk sources as identified in the study could be further broken down into seven sub-categories: design risks, external risks, environmental risks, organizational risks, project management risks, right of way risks, and construction risks which fall within the control of the project team. 


\begin{tabular}{|c|c|c|c|}
\hline & Categories & $\begin{array}{l}\text { Likelihood } \\
1 \text { (rare)-5 (very } \\
\text { frequent) }\end{array}$ & $\begin{array}{c}\text { Impact } \\
1 \text { (very low)-5 } \\
\text { (very high) }\end{array}$ \\
\hline \multicolumn{4}{|c|}{ Design risks } \\
\hline D1 & Design errors and omissions & 4 & 5 \\
\hline D2 & Design process takes longer than anticipated & 3 & 4 \\
\hline D3 & Stakeholders request late changes & 3 & 3 \\
\hline D4 & $\begin{array}{l}\text { Failure to carry out the works in accordance with } \\
\text { the contract }\end{array}$ & 3 & 3 \\
\hline \multicolumn{4}{|c|}{ External risks } \\
\hline Ex1 & New stakeholders emerge and request changes & 2 & 4 \\
\hline Ex2 & Public objections & 1 & 3 \\
\hline Ex3 & Laws and local standards change & 1 & 3 \\
\hline Ex4 & Tax change & 1 & 4 \\
\hline \multicolumn{4}{|c|}{ Environmental risks } \\
\hline En1 & Environmental analysis incomplete & 2 & 4 \\
\hline En2 & $\begin{array}{l}\text { New alternatives required to avoid, mitigate or } \\
\text { minimize environmental impact }\end{array}$ & 2 & 4 \\
\hline \multicolumn{4}{|c|}{ Organizational risks } \\
\hline $\mathrm{O} 1$ & Inexperienced workforce and staff turnover & 3 & 3 \\
\hline $\mathrm{O} 2$ & Delayed deliveries & 3 & 3 \\
\hline $\mathrm{O} 3$ & Lack of protection on a construction site & 2 & 4 \\
\hline \multicolumn{4}{|c|}{ Project management risks } \\
\hline PM1 & $\begin{array}{l}\text { Failure to comply with contractual quality } \\
\text { requirements }\end{array}$ & 3 & 4 \\
\hline PM2 & Scheduling errors, contractor delays & 4 & 4 \\
\hline PM3 & Project team conflicts & 3 & 3 \\
\hline \multicolumn{4}{|c|}{ Right of way risks } \\
\hline R1 & Expired temporary construction permits & 1 & 4 \\
\hline R2 & Contradictions in the construction documents & 2 & 3 \\
\hline \multicolumn{4}{|c|}{ Construction risks } \\
\hline $\mathrm{C} 1$ & Construction cost overruns & 4 & 4 \\
\hline C2 & Technology changes & 2 & 4 \\
\hline
\end{tabular}

Table 1. Risk categories 


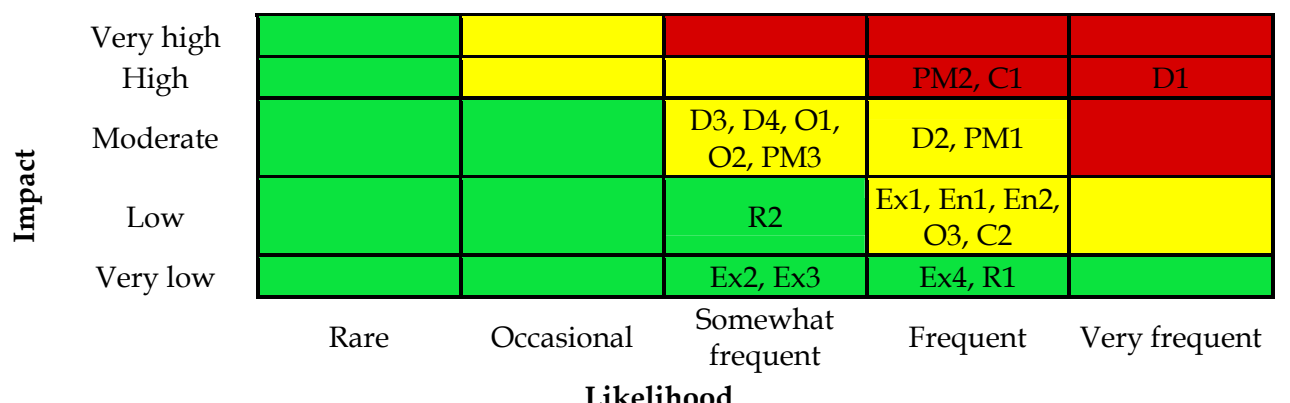

Figure 6. Risk matrix

Once the risks and probabilities are determined, the risk score can be calculated. Risk score is detailed in Table 1 . The probability and impact matrix (Fig. 6) illustrates a risk rating assignment for individual risk factors in the identified risks categories. The risk matrix shows the combination of impact and probability that in turn yield a risk priority (shown by the red, yellow, and green colour). Qualitative risk analysis can lead to further analysis in quantitative risk analysis or directly to risk response planning.

Twenty risk factors were established to be significant under the internal risks categories. Under the design risk category, design errors/omissions and design process delays were the most frequently mentioned risk factors attributed to the contractors. Under the project management risk category, scheduling errors and failure to comply with contractual quality requirements were the most frequently mentioned risk factors. Under the construction risk category, construction cost overruns and technology changes were the most frequently mentioned risk factors attributed to the contractors. Respondents believed that these risk events are responsible for poor quality of work, delays and associated losses. Risks with high impact and high probability, such as D1 (design errors and omissions), C1 (construction cost overruns), and PM2 (scheduling errors, contractor delays) are required further analysis, including quantification, and aggressive risk management.

\section{Conclusions}

An effective risk management process encourages the construction company to identify and quantify risks and to consider risk containment and risk reduction policies. Construction companies that manage risk effectively and efficiently enjoy financial savings, and greater productivity, improved success rates of new projects and better decision making.

Risk management in the construction project management context is a comprehensive and systematic way of identifying, analyzing and responding to risks to achieve the project objectives. The research results show that the Lithuanian construction company significantly differ from the construction companies in foreign countries in the adoption of risk management practices. To management the risk effectively and efficiently, the contractor must understand risk responsibilities, risk event conditions, risk preference, and risk management capabilities. 
The lack of experience makes it very difficult to change Lithuanian contractors' attitude towards risk management. Nevertheless, the construction companies need to include risk as an integral part of their project management. In our view, the use of risk management in the Lithuanian construction companies is low to moderate, with little differences between the types, sizes and risk tolerance of the organizations, and experience and risk tolerance of the individual respondents.

Qualitative methods of risk assessment are used in construction companies most frequently, ahead of quantitative methods. In construction project risk management, risks may be compared by placing them on a matrix of risk impact against a probability. Mitigation options are then derived from predefined limits to ensure the risk tolerance and appetite of the construction company.

The risk management framework for construction projects can be improved by combining qualitative and quantitative methodologies to risk analysis.

\section{Author details}

Nerija Banaitiene* and Audrius Banaitis

Department of Construction Economics and Property Management, Faculty of Civil Engineering, Vilnius Gediminas Technical University, Vilnius, Lithuania

\section{References}

[1] Statistics Lithuania. GDP by production, by expenditure, by income approach, IV Q 2011 (revised) and I Q 2012 (first estimate) [Internet]. Statistics Lithuania; 2005 [updated 2012 April 30; cited 2012 May 1]. Available from: http://www.stat.gov.lt/en/pages/view/?id=1867

[2] Global Finance. Lithuania: Country Economic Reports \& GDP data [Internet]. Global Finance; 2011 [cited 2012 April 1]. Available from: http://www.gfmag.com/gdp-datacountry-reports/231-lithuania-gdp-country-report.html\#axzz1tdm8vIK2

[3] Statistics Lithuania. Gross domestic product first estimate [Internet]. Statistics Lithuania; 2005 [updated 2012 April 30; cited 2012 May 1]. Available from:

http://www.stat.gov.lt/en/news/view?id=10755

[4] Project Management Institute. Guide to the project management body of knowledge (PMBOK® Guide). $4^{\text {th }}$ ed. Newtown Square: Project Management Institute; 2008.

[5] Institution of Civil Engineers and the Actuarial Profession. Risk analysis and management for projects (RAMP). $2^{\text {nd }}$ ed. Institution of Civil Engineers and the Actuarial Profession. London: Thomas Telford Ltd; 2005.

[6] Project Management Institute. Construction extension to the PMBOK® Guide. $3^{\text {rd }}$ ed. Newtown Square: Project Management Institute; 2007.

\footnotetext{
${ }^{*}$ Corresponding Author
} 
[7] Flanagan R, Norman G, Chapman R. Risk management and construction. 2 ${ }^{\text {nd }}$ ed. Oxford: Blackwell Pub; 2006.

[8] Mills A. A systematic approach to risk management for construction. St Surv 2001;19(5):245-252.

[9] Oyegoke AS. Construction industry overview in the UK, US, Japan and Finland: a comparative analysis. J Constr Res 2006;7(1/2):13-31.

[10] Pheng LS, Chuan QT. Environmental factors and work performance of project managers in the construction industry. Int J Project Manage 2006;24(1):4-37.

[11] Sterman JD. System dynamics modeling for project management [Internet]. Sloan School of Management, Massachusetts Institute of Technology; 1992 [cited 2012 May 1]. Available from: http://web.mit.edu/jsterman/www/SDG/project.pdf

[12] Uher TE, Loosemore M. Essentials of construction project management. Sidney: University of New South Wales Press; 2004.

[13] Dey PK, Ogunlana SO. Selection and application of risk management tools and techniques for build-operate-transfer projects. Ind Manage Data Syst 2004;104(4):334346.

[14] Cavignac J. Managing risk in a construction company [Internet]. Construction Business Owner 2009; November [cited 2012 March 10]. Available from:

http://www.constructionbusinessowner.com/topics/insurance/constructioninsurance/managing-risk-construction-company

[15] Eskesen SD, Tengborg P, Kampmann J, Veicherts TH. Guidelines for tunnelling risk management, International Tunnelling Association, Working Group No. 2-1. Tunn Undergr Sp Tech 2004;19(3):217-237.

[16] Keoki Sears S, Sears GA, Clough RH. Construction project management - A practical guide to field construction management. $5^{\text {th }}$ ed. Hoboken: John Wiley \& Sons; 2008.

[17] Dey PK. Issues and challenges of managing projects in India: A case study. In: Budhwar PS, Varma A, editors. Doing business in India: Building research-based practice. New York: Routledge; 2011.

[18] Dey PK, Ogunlana SO. Risk based decision support system for effective implementation of projects. Int J Risk Assess Manage 2002;3(2/3/4): 189-204.

[19] Zou PXW, Zhang G, Wang J. Understanding the key risks in construction projects in China. Int J Project Manage 2007;25(6):601-614.

[20] European Agency for Safety and Health at Work. Report - Prevention of risks in construction in practice [Internet]. Luxembourg: Office for Official Publications of the European Communities; 2004 [cited 2012 March 1]. Available from: http://osha.europa.eu/en/publications/reports/108/view

[21] Statistics Lithuania. Construction statistics [Internet]. Statistics Lithuania; 2005 [updated 2012 February 14; cited 2012 May 1]. Available from: http://www.stat.gov.lt/en/news/view/?id=10706

[22] State Labour Inspectorate of the Republic of Lithuania. Annual report on the state on employees' health and safety and labour law enforcement in Lithuanian companies, institutions and organizations [Internet]. Vilnius: State Labour Inspectorate of the 
Republic of Lithuania; 2011 [cited 2012 May 1]. Available from: http://www.vdi.lt/index.php?1716170122

[23] Ahmed A, Kayis B, Amornsawadwatana S. A review of techniques for risk management in projects. Benchmark Int J 2007;14(1):22-36.

[24] Cretu O, Stewart RB, Berends T. Risk management for design and construction (RSMeans). Hoboken: John Wiley \& Sons; 2011.

[25] Chapman C, Ward S. Project risk management: Process, techniques and insights. $2^{\text {nd }}$ ed. Chichester: John Wiley \& Sons; 2003.

[26] Klemetti A. Risk management in construction project networks. Helsinki University of Technology, Laboratory of Industrial Management, Report 2006/2, Espoo; 2006.

[27] Smith NJ, Merna T, Jobling P. Managing risk: in construction projects. $2^{\text {nd }}$ ed. Oxford: Blackwell Publishing; 2006.

[28] Wysocki RK. Effective project management: traditional, agile, extreme. Indianapolis: John Wiley \& Sons; 2009.

[29] Wang MT, Chou HY. Risk allocation and risk handling of highway projects in Taiwan. J Manage Eng 2003;19(2):60-68.

[30] Carbone TA, Tippett DD. Project risk management using the project risk FMEA. Eng Manage J 2004;16(4):28-35.

[31] Raz Z, Shenhar AJ, Dvir D. Risk management, project success and technological uncertainty. R\&D Manage 2002;32(2):101-109.

[32] Tah JHM; Carr V. A proposal for construction project risk assessment using fuzzy logic. Constr Manage Econ 2000;18(4):491-500.

[33] Wang SQ, Dulaimi MF, Aguria MY.): Risk management framework for construction projects in developing countries. Constr Manage Econ 2004;22(3):237-252.

[34] Adams FK. Construction contract risk management: a study of practices in the United Kingdom. Cost Eng 2008;50(1):22-33.

[35] Caltrans Office of Statewide Project Management Improvement. Project risk management handbook: Threats and opportunities. $2^{\text {nd }}$ ed. [Internet]. Sacramento: Caltrans; 2007 [cited 2012 May 1]. Available from:

http://www.dot.ca.gov/hq/projmgmt/documents/prmhb/caltrans_project_risk_manage ment_handbook_20070502.pdf

[36] Carr V, Tah JHM. A fuzzy approach to construction project risk assessment and analysis: construction project risk management system. Adv Eng Softw 2001;32(1011):847-857.

[37] Modarres M. Risk analysis in engineering - techniques, tools, and trends. $1^{\text {st }}$ ed. Boka Raton: CRC Press; 2006.

[38] Zwikael O, Sadeh A. Planning effort as an effective risk management tool. J Oper Manag 2007; 25(4):755-767.

[39] Hillson D. Developing effective risk responses. In Proceedings of the 30th Annual Project Management Institute Seminars \& Symposium, 10-16 October, 1999, Sylva. NC: Project Management Institute; 2000.

[40] Perera BAKS, Dhanasinghe I, Rameezdeen R. Risk management in road construction: the case of Sri Lanka. Int J St Prop Manage 2009;13(2):87-102. 
[41] Jannadi OA, Almishari S. Risk assessment in construction. J Constr Eng Managet 2003;129(5): 492-500.

[42] Simu K. Risk management in small construction projects [Licentiate Dissertation]. Department of Civil and Environmental Engineering, Luleå: LTU; 2006.

[43] Baloi D, Price ADF. Evaluation of global risk factors affecting cost performance in Mozambique [Internet]. London: RICS Foundation, COBRA; 2001 [cited 2012 March 11]. Available from: http://www.rics.org/site/download_feed.aspx?fileID=2483\&fileExtension=PDF

[44] Oyegoke AS, Khalfan MMA, McDermott P, Dickinson M. Managing risk and uncertainty in an agile construction environment: application of agile building specialist model. Int J Agile Syst Manage 2008;3(3-4):248-262.

[45] Assaf SA, Al-Hejji S. Causes of delay in large construction projects. Int J Proj Manage 2006;24(4):349-357.

[46] Aibinu AA, Odeyinka HA. Construction delays and their causative factors in Nigeria. J Constr Eng Manage 2006;132(7):667-677.

[47] Nasir D, McCabe B, Hartono L. Evaluating risk in construction-schedule model (ERICS): construction schedule risk model. J Constr Eng Manage 2003;129(5):518-527.

[48] Aramvareekul P, Seider DJ. Cost-time-risk diagram: project planning and management. Cost Eng 2006;48(11):12-18.

[49] European Commission. FWC sector competitiveness studies $N^{\circ}$ B1/ENTR/06/054 Sustainable competitiveness of the construction sector. Final report [Internet]. ECORYS SCS Group; November 2011 [cited 2012 January 21]. Available from: http://ec.europa.eu/enterprise/sectors/construction/files/compet/sustainable_competitiv eness/ecorys-final-report_en.pdf

[50] Lewicki RJ, Bunker BB. Developing and maintaining trust in work relationships. In: Kramer RM, Tyler TR, editors. Trust in organizations: frontiers of theory and research. Thousand Oaks: Sage Publications; 1996.

[51] Pinto JK, Slevin DP, English B. Trust in projects: An empirical assessment of owner/contractor relation-ships., Int J Proj Manage 2009; 27(6):638-648.

[52] Krane HP, Olsson NOE, Rolstadås A. How project manager-project owner interaction can work within and influence project risk management. Proj Manage J 2012;43(2):5467.

[53] Kaklauskas A, Zavadskas EK, Bagdonavicius A, Kelpsiene L, Bardauskiene D, Kutut V. Conceptual modelling of construction and real estate crisis with emphasis on comparative qualitative aspects description. Transformations in Business \& Economics 2010;9,1(19): 42-61.

[54] Chan APC, Chan DWM, Ho KSK. Partnering in construction: critical study of problems for implementation. J Manage Eng 2003;19:126-135.

[55] Brewer G, Strahorn S. Trust and the Project Management Body of Knowledge. Eng Constr Arch Manage 2012;19(3):286-305.

[56] Ward S, Chapman C. Stakeholders and uncertainty management in projects. Constr Manage Econ 2008;26(6):563-577. 
[57] Smyth H, Gustafsson M, Ganskau E. The value of trust in project business. Int J Proj Manage 2010;28(2): 117-129.

[58] Wilkinson S. An analysis of the problems faced by project management companies managing construction projects. Eng Constr Arch Manage 2001;8(3):160-170.

[59] Öztas A, Ökmen Ö. Risk analysis in fixed-price design-build construction projects. Build Environ 2004;39(2):229-237.

[60] Zaghloul R, Hartman F. Construction contracts: the cost of mistrust. Int J Proj Manage 2003;21(6):419-424.

[61] Chapman C, Ward S. Developing and implementing a balanced incentive and risk sharing contract. Constr Manage Econ 2008;26(6):659-669.

[62] Ökmen Ö, Öztas A. Construction cost analysis under uncertainty with correlated cost risk analysis mode. Constr Manage Econ 2010;28(2):203-212.

[63] Baloi D, Price ADF. Modeling global risk factors affecting construction cost performance. Int J Proj Manage 2003;21(4):261-269.

[64] Ismail A, Abbas MA, Zamri BC. Approach to analyze risk factors for construction projects utilizing fuzzy logic. J Appl Sci 2008,8(20):3738-3742.

[65] Zeng J, An M, Smith NJ. Application of a fuzzy based decision making methodology to construction project risk assessment. Int J Proj Manage 2007;25(6):589-600.

[66] Kartam NA, Kartam SA. Risk and its management in the Kuwaiti construction industry: a contractors' perspective. Int J Proj Manage 2001;9(6):325-335.

[67] Lahdenperä P. Phased multi-target areal development competitions: algorithms for competitor allocation. Int J St Prop Manage 2009;13(1):1-22.

[68] Majamaa W, Junnila S, Doloi H, Niemistö E. End-user oriented public-private partnerships in real estate industry. Int J St Prop Manage 2008;12(1):1-17.

[69] Mbachu J, Nkado R. Factors constraining successful building project implementation in South Africa. Constr Manage Econ 2007;25(1):39-54.

[70] Mitkus S, Trinkuniene E. Reasoned decisions in construction contracts evaluation. Technol Econ Dev Ec 2008;14(3):402-416.

[71] Yang J, Shen GQ, Ho M, Drew DS, Chan APC. Exploring critical success factors for stakeholder management in construction projects. J Civil Eng Manage 2009;15(4):337348.

[72] Savić S, Vučković L. Forming of reliability model in order to evaluate the operator's activity risk. Series: Working and Living Environmental Protection 2004;2(4):259-265.

[73] Zavadskas EK, Kaklauskas A, Banaitiene N. Multiple criteria analysis of a building life cycle. Vilnius: Technika; 2001. (in Lithuanian) 